\title{
Effect of Foliar Application With some Micronutrients on 'Florida Prince' Cultivar Peach Tree
}

\author{
Aly, M. A. ${ }^{1}$, Thanaa M. Ezz ${ }^{1}$, Nagwa A. Abd El-Megeed ${ }^{2}$ and \\ Mohamed I. Flefil ${ }^{1}$ \\ ${ }^{1}$ Plant Production Dept., Faculty of Agric., Saba Bacha, Alex. Univ. \\ ${ }^{2}$ Hort. Res. Institiute, Agric. Res. Center, Giza, Egypt
}

\begin{abstract}
This study was carried out during the two successive seasons 2015 and 2016 on five years old 'Florida prince' peach trees (Prunus persica L.) budded on 'Nemagard' peach rootstock, grown in sandy soil under drip irrigation system in a private orchard located at El-Nubaria region, El-Behira Governorate, Egypt. The aims of this research was to investigate the effect of some micronutrients foliar as Boric acid $\left(\mathrm{H}_{3} \mathrm{BO}_{3}\right)$, Zinc sulphate $\left(\mathrm{ZnSO}_{4}\right)$ and FeEDTA on yield, fruit quality and elemental composition of 'Florida prince' peach trees. The followed experimental design was randomized complete block design with five replicates. Results indicated that all the foliar application treatments, significantly increased the yield $(\mathrm{kg}$ /tree) and fruit weight $(\mathrm{g})$ as compared with control. The highest yield and fruit weight were recorded with $0.2 \%$ Fe-EDTA foliar application treatment $(99.85$ and $104.40 \mathrm{~kg} / \mathrm{tree}$, for two seasons) as compared with the control (36.87 and $37.38 \mathrm{~kg} /$ tree, respectively). Moreover, all Boric acid, Zinc sulphate and Fe-EDTA foliar treatments increased length $(\mathrm{cm})$, diameter $(\mathrm{cm})$, firmness $\left(\mathrm{Ib} / \mathrm{inch}^{2}\right)$, total soluble solids (\%), acidity (\%), and total sugars (\%) as compared with control ones during both seasons. On the other hand, A gradual elemental increases in Boron, Iron and Zinc in leaves (\%) were recorded with the micronutrient treatments as compared with the control plants.
\end{abstract}

Key words: 'Florida prince', Peach, Boric, Zinc, Iron, micronutrients, yield, fruit quality.

\section{INTRODUCTION}

Peach (Prunus persica L.) is one of the most important stone fruits, due to its heavy loading dietetic value and as a rich source of carbohydrate, protein and vitamins especially; $A, B$ and $C$ and some mineral nutrients according to FAOSTAT (2017), Egypt ranges third in the Arab production of peaches. The area cultivated with peach in Egypt is 58800 feddans, and total product of peach fruits is 360723 tons. To expand the peach market and to prolong the time of marketing, some early, mid and late season low chilling peach cultivars such as Florida sun, Florida prince, Desert Red, Early grand and swelling were introduced in the last several years, mainly from the U.S.A. by the Agriculture Development System (Mansour et al., 1982; Stino et al., 1982 and Shaltout, 1995).

There is strong evidence that zinc is an essential minor element for fungi and higher plants; but, it is found as traces. The low zinc supplies to plants in water cultures prevent moderate growth. Zinc plays an important role in several plant metabolic processes; it activates enzymes and is involved in protein synthesis and carbohydrate, nucleic acid and lipid metabolism (Pahlsson, 1989). Zinc is most important in the flowering and fruit set and the effect of foliar application of zinc on zinc uptake, yield and fruit quality of mango was investigated (Bahadur et al., 1998). In addition, Mahrous and El-Fakhrani (2000) mentioned that zinc sulphate significantly increased fruit weight, diameter, firmness and T.S.S. of apricot, meanwhile it decreased fruit acidity when compared with other treatments and the control. Also, Orphanos (2000) 
reported that apple zinc foliar application during the growing season increased the $\mathrm{Zn}$ content of the sprayed leaves even if they were just beginning to grow at the time of spraying. He added that spraying $Z n$-EDTA when the apical bud was bursting did not increase $\mathrm{Zn}$ in leaves produced from the lateral buds.

Boron deficiency causes fruit disorders and cracking or seaming (Benson et al., 1983). Kilany and Kilany (1991) working on 'Anna' apple and reported that boron sprays significantly increased the shoot length and diameter, boron has been recognized as an essential element for plant growth for more than later sixty years. Also, on 'Anna' apple trees, boric acid caused insignificant effect on fruits diameter, length volume and weight, but sprays increased acidity, total sugars and anthocyanin content (Mostafa et al., 1999). Moreover, has an important role in fruit quality is boron has an effect on cell wall structure and also has a major effect on cell elongation (Pollen tube) and root growth (Mahnaz et al ., 2010).

Iron had an important function in enzymatic systems and chlorophyll formation and consequently increased photosynthesis, which finally increased the yield (Aly et al., 2014). Iron spray was effective in increasing pear vegetative growth. Larue and Johanson (1989) stated that, foliar fertilizers as chelated should be easily absorbed by the plants and rapidly transported and should be easily release their ions to affect the plant of peach, plum nectarine. Pear trees suffer from colorosis on calcareous soil and iron can greatly correct this phenomenon (Westwood, 1993). The aim of this study is to investigate the effect of $\mathrm{Zn}, \mathrm{B}$ and $\mathrm{Fe}$ at different levels of application on yield, fruit quality and leaf mineral content of 'Florida prince' peach trees grown under sandy soil conditions.

\section{MATERIALS AND METHODS}

This investigation was conducted during two successive seasons 2015 and 2016 on five years old 'Florida prince' peach trees (Prunus persica L.) budded on 'Nemagard' peach rootstock, planted at $4 \times 3$ meters apart, grown in sandy soil under drip irrigation system in a private orchard located at El-Nubaria region, El-Behira Governortate, Egypt. Fifty trees as uniform as possible were selected for achieving this study. Trees were of normal growth, uniform in vigour and received normal fertilization and cultural practices as scheduled in the farm.

The physical determinations of $\mathrm{pH}$ and $\mathrm{EC}$ and organic matter $\%$ were measured. In addition, chemical determinations were carried on 1:5 soils: water extract, for total nitrogen content in soil $(\mathrm{mg} / \mathrm{kg})$, samples of soil were used for extraction of total nitrogen content $(\mathrm{mg} / \mathrm{kg})$ using Kjeldahl method. Samples of soil were used for extraction of phosphorus by using sodium bicarbonate method. Phosphorus was determind colorimetrically using the spectrophotometer at wave length of $660 \mathrm{~nm}$ according to James et al. (1989). Moreover soil samples for extraction of potassium by the distilled water (1:25) extraction. Potassium was determined by using the flame photometry according to James et al. (1989). $\mathrm{Ca}, \mathrm{Mg}, \mathrm{Na}, \mathrm{K}, \mathrm{Cl}$, total carbonate and $\mathrm{SO}_{4}$ were determined according to AOAC (1985). The analysis of experimental soil and was illustrated in Tables (1). 
Table (1).The physical and chemical properties of the experimental soil

\begin{tabular}{|c|c|c|}
\hline Parameter & $0-30 \mathrm{~cm}$ & $30-60 \mathrm{~cm}$ \\
\hline \multicolumn{3}{|l|}{ Mechanical Analysis (\%) } \\
\hline Sand & 96 & 98 \\
\hline Silt & -- & -- \\
\hline Clay & 4 & 2 \\
\hline Textural class & Sand & Sand \\
\hline $\mathrm{pH}(1: 1$, water suspension) & 8.24 & 8.53 \\
\hline EC (1:1,water extract), dS/m & 0.32 & 0.30 \\
\hline $\mathrm{CaCO}_{3}(\%)$ & 2.6 & 5.0 \\
\hline O.M $(\%)$ & 0.05 & 0.09 \\
\hline \multicolumn{3}{|l|}{ Soluble cations (meq/L) } \\
\hline $\mathrm{Ca}^{2+}$ & 2.72 & 3.06 \\
\hline $\mathrm{Mg}^{2+}$ & 1.70 & 0.34 \\
\hline $\mathrm{Na}^{+}$ & 1.85 & 1.63 \\
\hline $\mathrm{K}^{+}$ & 0.32 & 0.22 \\
\hline \multicolumn{3}{|l|}{ Soluble anions (meq/L) } \\
\hline $\mathrm{HCO}_{3}^{-}$ & 4.86 & 8.10 \\
\hline $\mathrm{Cl}-$ & 5.40 & 4.86 \\
\hline $\mathrm{SO}_{4}^{-}$ & 1.45 & 1.77 \\
\hline \multicolumn{3}{|l|}{ Available nutrients $(\mathrm{mg} / \mathrm{kg})$} \\
\hline Nitrogen $(\mathrm{N})$ & 202.61 & 222.14 \\
\hline Phosphorus(P) & 9.5 & 20.0 \\
\hline Potassium (K) & 250 & 300 \\
\hline
\end{tabular}

Fifty uniform trees, more or less, were selected for this study and all of them were subjected to the same cultural practices during both successive seasons.

The experiment involved the following treatments

1- Control (untreated trees)

2- $0.05 \%$ Boric acid $\left(\mathrm{H}_{3} \mathrm{BO}_{3}\right)$.

3- $0.1 \%$ Boric acid $\left(\mathrm{H}_{3} \mathrm{BO}_{3}\right)$.

4- $0.2 \%$ Boric acid $\left(\mathrm{H}_{3} \mathrm{BO}_{3}\right)$.

5- $0.05 \%$ Zinc sulphate $\left(\mathrm{ZnSO}_{4}\right)$.

6- $0.1 \%$ Zinc sulphate $\left(\mathrm{ZnSO}_{4}\right)$.

7- $0.2 \%$ Zinc sulphate $\left(\mathrm{ZnSO}_{4}\right)$.

8- $0.05 \%$ Fe-EDTA.

9- $0.1 \%$ Fe-EDTA.

10- $0.2 \%$ Fe-EDTA.

Treatments sprayed with Boric acid, Zinc sulphate and Fe-EDTA at two equal doses on the two taken after fruit set, and the month later. The previous treatments were applied and arranged in a randomized complete block design. Each treatment included five replicates with one tree for each replicate. The effect of the previous treatments were investigated via evaluating their influence on the follollowing parameters: 


\section{Yield}

The produced fruit yield on each replicate tree resulting from the applied treatments was expressed as number of fruits/tree and weight of fruits in $\mathrm{kg} /$ tree which was attained at harvest stage.

\section{Physical fruit characteristics}

Sample of 10 fruits per tree from each replicate was collected randomly at late April in both seasons, and then transported quickly to the laboratory to determine the physical and chemical fruit characteristics.

Average fruit weight ( $g /$ fruit), fruit samples were weighted and the average fruit weight for each replicate was calculated.

Average fruit length (L) and diameter (D), in $\mathrm{cm}$ were measured by using hand caliper. fruit firmness was expressed as $\left(\mathrm{lb} / \mathrm{inch}^{2}\right)$ according to (Magness and Taylor, 1982). Flesh firmness was measured in two opposite sides of the fruit using the Magness and Taylor Pressure.

Anthocyanin content (mg/100 g, f.w): anthocyanin content was determined at the stage of coloration (mg/100g fresh weigh) according to Rabino et al. (1977).

\section{Chemical fruit characteristics}

Regarding chemical fruit characteristics, samples of 10 fruits from each replicate was picked randomly at harvest to determine the following parameters: Total soluble solids (TSS \%), was used to determine the percentage of TSS by hand refractometer according to Chen and Mellenthin (1981).

Total acidity (\%) was determined as in fruit juice according to Chen and Mellenthin (1981). Five milliliters from the obtained juice were used to determine the titratable acidity.

Total sugars (\%); were determined in fresh fruit samples according to Malik and Singh (1980). Sugars were extracted from 5 gram fresh weight and determined by phenol sulfuric and Nelson arsenate - molybadate colorimetric methods for total and reducing sugars, respectively. The non-reducing sugars were calculated by the difference between total sugars and reducing sugars.

Boron, iron and zinc concentration were determined in leaves in both seasons by 20 leaves/tree samples which were taken from each treatments. The samples were washed with tap water and distilled water, and then oven dried at $70^{\circ} \mathrm{C}$ to constant weight and then ground. To determine the leaf mineral contents, ground material of each sample was digested with $\mathrm{H}_{2} \mathrm{SO}_{4}$ and $\mathrm{H}_{2} \mathrm{O}_{2}$ according to Wolf (1982). In the digested material, micronutrients (Fe, $\mathrm{Zn}$ and B) leaf contents were determined by Perkin Elmer Atomic Absorption Spectrophotometer according to Carter (1993). Boron was determined colorimetrically by the carmine method according to Hatcher and Wilcox (1950). The concentrations of $\mathrm{B}, \mathrm{Fe}$ and $\mathrm{Zn}$ were expressed as $\mathrm{mg} / \mathrm{kg}$, on dry weight basis.

\section{Statistical analysis}

Results of the measured parameters were subjected to computerized statistical analysis using RCBD for analysis of variance (ANOVA) and means of treatments were compared using L.S.D at 0.05 probability level according to Snedecor and Cochran (1990). 


\section{RESULTS AND DISCUSSION}

\section{Yield components:}

\subsection{Number of fruits per tree:}

The results representing the effect of the above mentioned treatments on number of fruits per tree 'Florida prince' peach trees during both 2015 and 2016 seasons are show in Table (2). In general, the obtained results indicated that all foliar application treatments, significantly $(p \leq 0.05)$ increased number of fruit per tree as compared with the control during both experimental seasons. Foliar application with $0.2 \%$ Fe-EDTA treatments, gave rise to the highest increment in number of fruits per tree, followed by $0.1 \%$ Fe-EDTA foliar treatment in the first seasons and $0.2 \% \mathrm{ZnSO}_{4}$ treatment in second seasons as compared with the control during both 2015 and 2016 seasons.

A gradual increase in number of fruits per tree was observed with trees treated with $0.2 \%$ Fe-EDTA foliar treatments (851.33 and 874.67, each in turn) as compared with the control (482.67 and 487.90, each in turn). And, $0.1 \% \mathrm{Fe}-$ EDTA foliar application treatment (764.44), followed by $0.2 \% \mathrm{ZnSO}_{4}$ foliar application treatment (757.92), and $0.1 \% \mathrm{H}_{3} \mathrm{BO}_{3}$ foliar application treatment (747.35) in the first seasons as compared with the control (482.67). While, in the second season $0.1 \%$ Fe- EDTA (771.67), and $0.1 \%$ Boric acid foliar application treatments (763.67) as compared with the control (487.90).

The increment of number of fruit per tree comparing to check plot may be due to the direct effects of Khalifa et al. (2009) on 'Anna' apple trees sprayed with boric acid increase the average number of fruit per tree and yield. Also, Aly et al. (2014) on 'Anna' apple trees who reported that the treatment of boric acid significantly increased the number of fruit per tree. Also, Abd El-Rahman (2019) on 'Canino' apricot trees found that all foliar boric acid application significantly increased number of fruits per tree as compared with the control during both experimental seasons.

\subsection{Fruit weight $(g)$ :}

As for the effects of zinc sulphate, boric acid and Fe- EDTA foliar treatments on fruit weight of 'Florida prince' peach trees during both 2015 and 2016 seasons, results in Table (2) showed that all treatments, $(p \leq 0.05)$ increased fruit weight as compared with the control treatment. $0.2 \%$ Fe-EDTA foliar application treatment gave rise to the highest fruit weight (117.33 and $119.33 \mathrm{~g}$ each in turn), followed by $0.1 \%$ Fe-EDTA foliar treatment (100.40 and $101.33 \mathrm{~g}$ each in turn), and $0.05 \%$ Fe-EDTA foliar treatments (99.00 and $101.00 \mathrm{~g}$ each in turn), and $0.1 \% \mathrm{ZnSO}_{4}$ foliar application treatment (92.67 and $94.67 \mathrm{~g}$ ) as compared with the control (76.33 and $76.67 \mathrm{~g}$ ) during both 2015 and 2016 seasons. Generally, foliar application with Fe-EDTA caused higher fruit weigh during both 2015 and 2016 seasons as compared with the control.

These results are in agreement with those reported by Asad et al. (2013) they found that, foliar applications of micronutrients on 'Le- Conte' pear trees increased yield as $\mathrm{kg} / \mathrm{tree}$ and fruit weight. Also, Aly et al. (2014) found that significant difference was achieved by foliar application of $\mathrm{H}_{3} \mathrm{BO}_{3}$ treatments on average fruit weight ( $\mathrm{g} /$ fruit) of 'Anna' apple trees in both seasons. 


\subsection{Yield ( $\mathrm{kg} /$ tree):}

The results concerning the effect of zinc sulphate, boric acid and FeEDTA foliar treatments on yield ( $\mathrm{kg} / \mathrm{tree}$ ) of 'Florida prince' peach trees during both 2015 and 2016 seasons, listed in Table (2). The average values of both experimental seasons indicated that all treatments, significantly $(p \leq 0.05)$ increased yield $(\mathrm{kg} / \mathrm{tree})$ as compared with the control. It was evident that the application of $0.2 \%$ Fe-EDTA foliar application treatment, take about the highest increment in yield $(\mathrm{kg})$, followed by $0.1 \%$ Fe-EDTA foliar treatment as compared with the control during both seasons 2015 and 2016.

Increasing in yield $(\mathrm{kg} / \mathrm{tree})$ was observed with trees treated with $0.2 \%$ Fe-EDTA foliar application treatment $(99.85$ and $104.40 \mathrm{~kg}$, each in turn) and $0.1 \%$ Fe-EDTA foliar application treatment (76.82 and $78.14 \mathrm{~kg}$, each in turn), followed by $0.1 \% \mathrm{ZnSO}_{4}$ foliar application treatment $(69.34$ and $71.91 \mathrm{~kg}$, each in turn) as compared with the control (36.87 and $37.38 \mathrm{~kg}$, each in turn) during both 2015 and 2016.

These results are in agreement with those reported by Wojcik (2002) on 'junagod' apple fruits, they found that increasing B concentration decreased fruit weight and when tree yield was high, mean fruit weight was can consistently lower. Also, Aly et al. (2014) on 'Anna' apple trees who noticed that the treatment of boric acid significantly increased yield ( $\mathrm{kg} / \mathrm{tree}$ ) as compared with the control treatment.

Table (2).The influence of the foliar application of zinc, boron and iron on number of fruits/tree, fruit weight $(\mathrm{g})$ and yield $(\mathrm{kg} / \mathrm{tree})$ of 'Florida prince' peach trees during 2015 and 2016 seasons

\begin{tabular}{|c|c|c|c|c|c|c|}
\hline \multirow{2}{*}{ Treatments } & \multicolumn{2}{|c|}{$\begin{array}{l}\text { Number of } \\
\text { fruits/ tree }\end{array}$} & \multicolumn{2}{|c|}{$\begin{array}{l}\text { Fruit weight } \\
\text { (g) }\end{array}$} & \multicolumn{2}{|c|}{$\begin{array}{c}\text { Yield } \\
\text { (kg/tree) }\end{array}$} \\
\hline & 2015 & 2016 & 2015 & 2016 & 2015 & 2016 \\
\hline 1- Control & $482.67^{d}$ & $487.90^{f}$ & $76.33^{\mathrm{C}}$ & $76.67^{d}$ & $36.87^{f}$ & $37.38^{\mathrm{g}}$ \\
\hline $2-0.05 \% \mathrm{ZnSO}_{4}$ & $652.33^{c}$ & $682.67^{c}$ & $85.50^{\mathrm{bc}}$ & $87.50^{\mathrm{bcd}}$ & $55.73^{\mathrm{de}}$ & $59.75^{\text {def }}$ \\
\hline $3-0.1 \% \mathrm{ZnSO}_{4}$ & $747.08^{b}$ & $760.00^{b}$ & $92.67^{\mathrm{bc}}$ & $94.67^{\mathrm{bc}}$ & $69.34^{\mathrm{bc}}$ & $71.91^{b c}$ \\
\hline 4- $0.2 \% \mathrm{ZnSO}_{4}$ & $757.92^{b}$ & $776.67^{\mathrm{b}}$ & $88.00^{\mathrm{bc}}$ & $90.00^{\mathrm{bcd}}$ & $66.67^{\mathrm{bcd}}$ & $69.89^{\mathrm{bcd}}$ \\
\hline 5- $0.05 \% \mathrm{H}_{3} \mathrm{BO}_{3}$ & $632.44^{c}$ & $637.33^{\mathrm{e}}$ & $78.33^{\mathrm{C}}$ & $80.33^{\mathrm{cd}}$ & $49.53^{e}$ & $51.21^{f}$ \\
\hline 6- $0.1 \% \mathrm{H}_{3} \mathrm{BO}_{3}$ & $747.35^{\mathrm{b}}$ & $763.67^{b}$ & $85.00^{\mathrm{bc}}$ & $87.00^{\mathrm{bcd}}$ & $63.53^{\mathrm{cd}}$ & $66.43^{\text {cde }}$ \\
\hline 7- $0.2 \% \mathrm{H}_{3} \mathrm{BO}_{3}$ & $655.67^{b}$ & $656.00^{\mathrm{de}}$ & $87.27^{\text {bc }}$ & $88.61^{\text {bcd }}$ & $57.22^{\text {de }}$ & $58.13^{\text {ef }}$ \\
\hline 8- $0.05 \%$ Fe-EDTA & $647.33^{c}$ & $667.67^{\mathrm{cd}}$ & $99.00^{b}$ & $101.00^{b}$ & $63.92^{\mathrm{cd}}$ & $67.58^{\mathrm{bcde}}$ \\
\hline 9- $0.1 \%$ Fe-EDTA & $764.33^{b}$ & $771.67^{b}$ & $100.40^{a b}$ & $101.33^{b}$ & $76.82^{b}$ & $78.14^{b}$ \\
\hline 10- $0.2 \%$ Fe-EDTA & $851.33^{a}$ & $874.67^{a}$ & $117.33^{a}$ & $119.33^{a}$ & $99.85^{\mathrm{a}}$ & $104.40^{a}$ \\
\hline
\end{tabular}

Means not sharing the same letter (s) within each column are significantly different at 0.05 level of probability.

\section{Fruit physical parameters:}

\subsection{Fruit length $(\mathrm{cm})$ :}

The results representing the effect of above mentioned treatment on fruit length $(\mathrm{cm})$ of 'Florida prince' peach trees was calculated and tabulated in Table (3). The obtained results indicated that all treatments, significantly $(p \leq 0.05)$ increased fruit length as compared with the control during both seasons 2015 and 2016. 
A gradual increase in fruit length was observed trees treated with $0.1 \%$ Fe-EDTA foliar application treatment $(5.68 \mathrm{~cm})$, and for the $0.05 \% \mathrm{ZnSO}_{4}$ foliar application treatment $(5.64 \mathrm{~cm})$, also $0.2 \%$ Fe-EDTA foliar treatment $(5.62 \mathrm{~cm})$, follower by $0.2 \%$ Zinc sulphate foliar application treatment $(5.61 \mathrm{~cm})$ in the first seasons. While in the second seasons, a gradual increase was observed with trees treated with $0.1 \%$ Fe-EDTA foliar application treatment $(5.77 \mathrm{~cm})$, and 0.2 $\%$ Fe-EDTA foliar application treatment $(5.70 \mathrm{~cm})$, and $0.05 \% \mathrm{ZnSO}_{4}$ foliar application treatment $(5.67 \mathrm{~cm})$, followed by $0.1 \%$ Boric acid foliar treatment $(5.58 \mathrm{~cm})$ as compared with the control $(5.12 \mathrm{~cm})$.

The obtained results were previously explained by Asad et al. (2013) who mentioned that foliar applications of micronutrients on 'Le- Conte' pear trees increased fruit length, diameter. Also, Aly et al. (2014) noticed that foliar application of $0.3 \% \mathrm{H}_{3} \mathrm{BO}_{3}$ achieved the highest average fruit length as compared with the control during both experimental seasons. Also, Abd ElRahman (2019) found that boric acid at $1.5 \% \mathrm{~g} / \mathrm{l}$ application on 'Canino' apricot trees treatment significantly increased fruit length as compared with the control during both experimental seasons.

\subsection{Fruit diameter $(\mathrm{cm})$ :}

Results express the effect of experimental treatments on fruit diameter (cm) of 'Florida prince' peach trees during both 2015 and 2016 seasons are showed in Table (3). The obtained results indicated that all Zinc sulphate, Boric acid and Fe-EDTA foliar treatments, significantly $(p \leq 0.05)$ increased fruit diameter as compared with the control during both seasons 2015 and 2016.

The increase in fruit diameter was observed with trees treated with 0.05 $\%$ Fe-EDTA foliar application treatment $(5.37 \mathrm{~cm})$, and $0.1 \% \mathrm{H}_{3} \mathrm{BO}_{3}$ foliar application treatment $(5.29 \mathrm{~cm})$, followed by0.2 \% $\mathrm{H}_{3} \mathrm{BO}_{3}$ foliar application treatment $(5.28 \mathrm{~cm})$, also $0.2 \%$ Fe-EDTA application treatment $(5.24 \mathrm{~cm})$ as compared with the control $(4.54 \mathrm{~cm})$ in the first seasons. while in the second seasons a gradual increase was observed with trees treated with $0.1 \% \mathrm{Fe}-$ EDTA and $0.05 \%$ Fe-EDTA foliar application treatments $(5.43 \mathrm{~cm}$ and 5.43 $\mathrm{cm})$, and $0.1 \% \mathrm{H}_{3} \mathrm{BO}_{3}$ treatment $(5.36 \mathrm{~cm})$, and $0.2 \%$ Fe-EDTA foliar application treatment $(5.34 \mathrm{~cm})$, followed by $0.2 \% \mathrm{ZnSO}_{4}$ foliar application treatment $(5.25 \mathrm{~cm})$ as compared with the control $(4.63)$.

The percentage increase of fruit diameter comparing to check my be due to the direct effects of these results are in agreement with those reported by Asad et al. (2013) reported that, foliar applications of micronutrients on 'LeConte' pear trees increased yield as $\mathrm{kg} / \mathrm{tree}$, fruit weight, diameter, firmness. Also, boron and potassium increase the rate of transport to actively growing regions and also in developing fruits.

\subsection{Fruit firmness $\left(\mathrm{lb} / \mathrm{inch}^{2}\right)$ :}

In regard to the results concerning the effect of studied foliar applications with boric acid, zinc sulphate and Fe-EDTA foliar treatments on the fruit firmness (Ib/inch ${ }^{2}$ ) of 'Florida prince' peach trees during both 2015 and 2016 seasons are listed in Table (3). The average values of both experimental seasons indicated that all foliar application treatments, significantly ( $p \leq 0.05)$ 
increased fruit firmness as compared with the control during both experimental seasons.

The increase in fruit firmness $\left(\mathrm{lb} / \mathrm{inch}^{2}\right)$ was observed with trees treated with $0.2 \% \mathrm{ZnSO}_{4}$ foliar application treatment (32.11),0.2 \% Fe-EDTA foliar treatment (31.19) and $0.1 \%$ Fe-EDTA foliar treatment (25.78) and $0.05 \%$ $\mathrm{ZnSO}_{4}$ foliar application treatment (23.68) as compared with the control (17.30) While, in second seasons $0.2 \%$ Fe-EDTA foliar treatment (32.26) and $0.1 \%$ $\mathrm{ZnSO}_{4}$ foliar application treatment (32.25) and $0.1 \%$ Fe-EDTA treatment (26.33) and $0.05 \% \mathrm{ZnSO}_{4}$ foliar application treatment (25.42) as compared with the control (18.92).

The increase in firmness might be related to the increase of fruit calcium content. Also, Khalifa et al. ( 2009) found that increasing B concentration increased fruit firmness of 'Anna' apple trees. Also, Asad et al. (2013) reported that, foliar applications of micronutrients on 'Le-Conte' pear trees increased yield as $\mathrm{kg} / \mathrm{tree}$, fruit weight, diameter, firmness, TSS and acidity, while decreased total sugars.

Table (3). The influence of the foliar application of zinc, boron and iron on Fruit length (cm), fruit diameter $(\mathrm{cm})$ and fruit firmness $\left(\mathrm{lb} / \mathrm{inch}^{2}\right)$ of 'Florida prince' peach trees during 2015 and 2016 seasons

\begin{tabular}{ccccccc}
\hline & \multicolumn{2}{c}{$\begin{array}{c}\text { Fruit Length } \\
\text { (cm) }\end{array}$} & \multicolumn{2}{c}{$\begin{array}{c}\text { Fruit diameter } \\
\text { (cm) }\end{array}$} & \multicolumn{2}{c}{$\begin{array}{c}\text { Fruit firmness } \\
\text { (lb/inch }\end{array}$} \\
\cline { 2 - 7 } Treatments & $\mathbf{2 0 1 5}$ & $\mathbf{2 0 1 6}$ & $\mathbf{2 0 1 5}$ & $\mathbf{2 0 1 6}$ & $\mathbf{2 0 1 5}$ & $\mathbf{2 0 1 6}$ \\
\hline 1- Control & $5.07^{\mathrm{b}}$ & $5.12^{\mathrm{b}}$ & $4.54^{\mathrm{b}}$ & $4.63^{\mathrm{b}}$ & $17.30^{\mathrm{c}}$ & $18.92^{\mathrm{bc}}$ \\
2- $0.05 \% \mathrm{ZnSO}_{4}$ & $5.64^{\mathrm{a}}$ & $5.68^{\mathrm{a}}$ & $5.19^{\mathrm{a}}$ & $5.25^{\mathrm{a}}$ & $23.68^{\mathrm{b}}$ & $25.42^{\mathrm{abc}}$ \\
3- $0.1 \% \mathrm{ZnSO}_{4}$ & $5.25^{\mathrm{ab}}$ & $5.45^{\mathrm{ab}}$ & $5.07^{\mathrm{a}}$ & $5.08^{\mathrm{a}}$ & $32.11^{\mathrm{a}}$ & $32.25^{\mathrm{a}}$ \\
4- $0.2 \% \mathrm{ZnSO}_{4}$ & $5.61^{\mathrm{a}}$ & $5.57^{\mathrm{a}}$ & $5.15^{\mathrm{a}}$ & $5.25^{\mathrm{a}}$ & $18.80^{\mathrm{c}}$ & $20.42^{\mathrm{bc}}$ \\
$5-0.05 \% \mathrm{H}_{3} \mathrm{BO}_{3}$ & $5.35^{\mathrm{ab}}$ & $5.38^{\mathrm{ab}}$ & $5.12^{\mathrm{a}}$ & $5.12^{\mathrm{a}}$ & $17.22^{\mathrm{c}}$ & $18.56^{\mathrm{c}}$ \\
6- $0.1 \% \mathrm{H}_{3} \mathrm{BO}_{3}$ & $5.52^{\mathrm{ab}}$ & $5.58^{\mathrm{a}}$ & $5.29^{\mathrm{a}}$ & $5.36^{\mathrm{a}}$ & $17.18^{\mathrm{c}}$ & $18.53^{\mathrm{c}}$ \\
7- $0.2 \% \mathrm{H}_{3} \mathrm{BO}_{3}$ & $5.44^{\mathrm{ab}}$ & $5.50^{\mathrm{ab}}$ & $5.28^{\mathrm{a}}$ & $5.23^{\mathrm{a}}$ & $16.95^{\mathrm{c}}$ & $18.26^{\mathrm{c}}$ \\
8- 0.05\% Fe-EDTA & $5.52^{\mathrm{ab}}$ & $5.47^{\mathrm{ab}}$ & $5.37^{\mathrm{a}}$ & $5.43^{\mathrm{a}}$ & $21.51^{\mathrm{bc}}$ & $22.33^{\mathrm{bc}}$ \\
9- 0.1\% Fe-EDTA & $5.68^{\mathrm{a}}$ & $5.77^{\mathrm{a}}$ & $5.17^{\mathrm{a}}$ & $5.43^{\mathrm{a}}$ & $25.78^{\mathrm{b}}$ & $26.33^{\mathrm{ab}}$ \\
10- $0.2 \% \mathrm{Fe}-\mathrm{FDTA}$ & $5.62^{\mathrm{a}}$ & $5.70^{\mathrm{a}}$ & $5.24^{\mathrm{a}}$ & $5.34^{\mathrm{a}}$ & $31.19^{\mathrm{a}}$ & $32.26^{\mathrm{a}}$ \\
\hline
\end{tabular}

Means not sharing the same letter (s) within each column are significantly different at 0.05 level of probability.

\section{Fruit chemical parameters:}

\subsection{Total soluble solids (\%):}

In concerning with influence of boric acid, zinc sulphate and Fe-EDTA foliar application treatments on the total soluble solids of 'Florida prince' peach trees during both 2015 and 2016 seasons, data in Table (4) cleared that all treatments, significantly ( $p \leq 0.05$ ) increased total soluble solids as compared with the control during both experimental seasons. A gradual increase in total soluble solids was observed with trees treated with $0.2 \% \mathrm{H}_{3} \mathrm{BO}_{3}$ foliar treatment (11.33 and $12.33 \%$, each in turn), and $0.1 \% \mathrm{H}_{3} \mathrm{BO}_{3}$ foliar treatment (11.04 and $12.00 \%$, each in turn), and $0.1 \% \mathrm{ZnSO}_{4}$ treatment (10.81 and $11.75 \%$, serially), followed by 10.67 and 11.67 , respectively) as compared with the control during both experimental seasons. 
The percentage increase of total soluble solids (\%) comparing to check may be due to the direct effects of these results are in agreement with those reported by Mahrous and El-Fakhrani (2000) mentioned that zinc sulphate increased significantly T.S.S. of apricot. Also, Wally et al. (2012) found that spraying chelated zinc at $0.2 \%+0.5 \%$ urea on 'Canino' apricot recorded the highest yield and improved fruit quality as compared with control. Also, Abd ElRahman (2019) on 'Canino' apricot trees found that boric acid at 0.5, 1 and 1.5 $\mathrm{g} / \mathrm{l}$ application treatments significantly increased total soluble solids as compared with the control during both experimental seasons.

\subsection{Acidity (\%):}

Results concerning the effect of foliar with zinc sulphate, boric acid and Fe-EDTA application treatments on the acidity (\%) of 'Florida prince' peach trees during both 2015 and 2016 seasons are listed in Table (4). Fe-EDTA treatments, significantly ( $p \leq 0.05)$ increased acidity $(\%)$ as compared with the control during both experimental seasons, while no significantly differences were recorded between Zinc sulphate and Boric acid treatments as compared with the control during both 2015 and 2016 seasons.

A gradual increase in acidity (\%) was observed with trees treated with 0.2 $\%$ Fe-EDTA foliar treatment ( 0.60 and $0.62 \%$, each in turn) and $0.1 \% \mathrm{Fe}-$ EDTA foliar treatment ( 0.59 and $0.61 \%$ serially), followed by $0.05 \%$ Fe-EDTA foliar treatment ( 0.56 and $0.57 \%$, respectively) as compared with the control ( 0.52 and $0.52 \%$, each in turn) during both 2015 and 2016 seasons. But, no significantly differences were recorded between $\mathrm{ZnSO}_{4}$ and $\mathrm{H}_{3} \mathrm{BO}_{3}$ foliar treatments as compared with the control during both 2015 and 2016 seasons.

The percentage increase of acidity (\%) comparing to check plot may be due to the direct effects as reported by Mahrous and El-Fakhrani (2000) mentioned that zinc sulphate increased significantly T.S.S. of apricot; meanwhile it decreased fruit acidity as compared with other treatments and the control. Also, Aly et al. (2012) on 'le-Conte' pear trees found that all boric acid concentrations decrease acidity \% as compared with the control. Abd ElRahman (2019) on 'Canino' apricot trees reported that a gradual decrease in fruit juice acidity was observed with trees treated with boric acid at $1.5 \mathrm{~g} / \mathrm{l}$ treatment as compared with the control during both experimental seasons.

\subsection{Anthocynin (mg/100 g f.w.):}

In concerning the effect of zinc sulphate, Fe-EDTA and boric acid foliar treatments on anthocynin of 'Florida prince' peach during the both 2015 and 2016 seasons, are listed in Table (4). The results of both experimental seasons indicated that, all treatments, significantly $(p \leq 0.05)$ increased anthocynin as compared with the control, while no significantly between the Fe-EDTA foliar treatment and control during both 2015 and 2016 seasons.

A gradual increase in anthocyanin was observed with trees treated with $0.2 \% \mathrm{H}_{3} \mathrm{BO}_{3}$ foliar treatment (20.91 and $22.84 \mathrm{mg} / 100 \mathrm{~g} \mathrm{f.w}$, each in turn), and $0.1 \% \mathrm{H}_{3} \mathrm{BO}_{3}$ foliar treatment (20.16 and $21.97 \mathrm{mg} / 100 \mathrm{~g}$ f.w, serially), followed by $0.05 \% \mathrm{H}_{3} \mathrm{BO}_{3}$ foliar treatment (19.13 and $21.02 \mathrm{mg} / 100 \mathrm{~g}$ f.w, respectively) and $0.2 \% \mathrm{ZnSO}_{4}$ foliar treatment (18.61 and $20.58 \mathrm{mg} / 100 \mathrm{~g}$ f.w, each in turn) 
as compared with the control (17.65 and $19.54 \mathrm{mg} / 100 \mathrm{~g}$ f.w.) during both experimental seasons.

The percentage increase of anthocynin comparing to check plot may be due to the direct effects as reported by Aly et al. (2014) who found that increasing rates of $\mathrm{K}$ and $\mathrm{B}$ as foliar application gradually led to increasing content of anthocynin (mg/100g) significantly in 'Anna' apple fruits as all remainder and control treatments in both seasons.

\subsection{Total sugars (\%):}

The results given in Table (4) represent the effect of used treatments on total sugars (\%) of 'Florida prince' peach during the both studied seasons. The results indicated that boric acid and zinc sulphate foliar application treatments, significantly ( $p \leq 0.05$ ) increased total sugars as compared with the control. While, no significant effect recorded between the Fe-EDTA treatment and control treatment during both 2015 and 2016 seasons.

A gradual increase in fruit total sugars was observed with trees treated with $0.2 \% \mathrm{H}_{3} \mathrm{BO}_{3}$ foliar treatment $(7.44$ and $8.07 \%$, each in turn), and $0.2 \%$ $\mathrm{ZnSO}_{4}$ foliar treatment (6.89 and $7.86 \%$, each in turn) as compared with the control (6.63 and $7.54 \%$, each in turn), and increase in fruit total sugars was observed with trees treated with $0.05 \% \mathrm{ZnSO}_{4}$ foliar treatment $(6.88 \%)$ and 0.1 $\% \mathrm{H}_{3} \mathrm{BO}_{3}$ foliar treatment $(6.85 \%)$ in the first seasons as compared with the control $(6.63 \%)$. While in the second seasons increase in fruit total sugars was observed with trees treated with $0.1 \% \mathrm{H}_{3} \mathrm{BO}_{3}$ foliar treatment $(7.83 \%)$, and 0.05 $\% \mathrm{ZnSO}_{4}$ foliar treatment $(7.74 \%)$ as compared with the control $(7.54 \%)$.

The percentage increase of total sugars (\%) comparing to check plot may be due to the direct effects as reported by Khalifa et al. (2009) on 'Anna' apple fruits who reported that increasing $B$ concentration increased sugars in fruit. Also, Aly et al .2014) on 'Anna' apple fruits found that the application of Ca or $\mathrm{Zn}$ did not affect significantly on total sugars \%, while foliar application of $\mathrm{H}_{3} \mathrm{BO}_{3}$ treatments significantly increased the total sugars \% in fruits as compared with the control treatment in both experimental seasons. Also, Abd El-Rahman (2019) on 'Canino' apricot trees reported that $1.5 \mathrm{~g} / \mathrm{l}$ gave the highest treatments on total sugars (\%) in two seasons (2017 and 2018) as compared with the control during both experimental seasons. 
Table (4). The influence of the foliar application of zinc, boron and iron on TSS (\%), acidity (\%), anthocynin (mg/100g.f.w.) and total sugars (\%) of 'Florida prince' peach trees during 2015 and 2016 seasons

\begin{tabular}{|c|c|c|c|c|c|c|c|c|}
\hline \multirow[t]{2}{*}{ Treatments } & \multicolumn{2}{|c|}{$\begin{array}{l}\text { TSS } \\
(\%)\end{array}$} & \multicolumn{2}{|c|}{$\begin{array}{c}\text { Acidity } \\
(\%)\end{array}$} & \multicolumn{2}{|c|}{$\begin{array}{l}\text { Anthocynin } \\
\text { (mg/100g.f.w.) }\end{array}$} & \multicolumn{2}{|c|}{$\begin{array}{c}\text { Total sugars } \\
(\%)\end{array}$} \\
\hline & 2015 & 2016 & 2015 & 2016 & 2015 & 2016 & 2015 & 2016 \\
\hline 1- Control & $8.58^{\mathrm{e}}$ & $8.50^{d}$ & $0.52^{c}$ & $0.52^{\mathrm{c}}$ & $17.65^{\mathrm{d}}$ & $19.54^{d}$ & $6.63^{b}$ & $7.54^{\text {de }}$ \\
\hline $2-0.05 \% \mathrm{ZnSO}_{4}$ & $9.83^{d}$ & $10.67^{\mathrm{c}}$ & $0.48^{d}$ & $0.49^{d}$ & $17.84^{d}$ & $19.76^{\mathrm{d}}$ & $6.88^{\mathrm{b}}$ & $7.74^{\mathrm{bc}}$ \\
\hline 3- $0.1 \% \mathrm{ZnSO}_{4}$ & $10.81^{\mathrm{abc}}$ & $11.75^{\mathrm{abc}}$ & $0.46^{\mathrm{de}}$ & $0.47^{\mathrm{de}}$ & $17.81^{d}$ & $19.70^{d}$ & $6.78^{b}$ & $7.69^{c}$ \\
\hline $4-0.2 \% \mathrm{ZnSO}_{4}$ & $10.33^{b c d}$ & $11.33^{\mathrm{abc}}$ & $0.46^{\text {de }}$ & $0.47^{\mathrm{de}}$ & $18.61^{\mathrm{c}}$ & $20.58^{c}$ & $6.89^{b}$ & $7.86^{b}$ \\
\hline 5- $0.05 \% \mathrm{H}_{3} \mathrm{BO}_{3}$ & $10.33^{b c d}$ & $11.33^{\mathrm{abc}}$ & $0.48^{d}$ & $0.49^{d}$ & $19.13^{c}$ & $21.02^{C}$ & $6.84^{b}$ & $7.73^{b c}$ \\
\hline 6- $0.1 \% \mathrm{H}_{3} \mathrm{BO}_{3}$ & $11.04^{\mathrm{ab}}$ & $12.00^{\mathrm{ab}}$ & $0.45^{\mathrm{e}}$ & $0.46^{\mathrm{e}}$ & $20.16^{b}$ & $21.97^{b}$ & $6.85^{\mathrm{b}}$ & $7.83^{b}$ \\
\hline 7- $0.2 \% \mathrm{H}_{3} \mathrm{BO}_{3}$ & $11.33^{a}$ & $12.33^{\mathrm{a}}$ & $0.41^{f}$ & $0.42^{f}$ & $20.91^{a}$ & $22.84^{\mathrm{a}}$ & $7.44^{\mathrm{a}}$ & $8.07^{a}$ \\
\hline 8- $0.05 \%$ Fe-EDTA & $8.83^{\mathrm{e}}$ & $9.17^{d}$ & $0.56^{b}$ & $0.57^{b}$ & $17.37^{d}$ & $19.26^{d}$ & $6.69^{b}$ & $7.63^{\mathrm{cd}}$ \\
\hline 9- $0.1 \%$ Fe-EDTA & $10.00^{\mathrm{cd}}$ & $11.00^{b c}$ & $0.59^{a}$ & $0.61^{a}$ & $17.31^{d}$ & $19.23^{d}$ & $6.60^{\mathrm{b}}$ & $7.43^{\mathrm{e}}$ \\
\hline 10- $0.2 \%$ Fe-EDTA & $10.67^{\mathrm{abcd}}$ & $11.67^{\mathrm{abc}}$ & $0.60^{a}$ & $0.62^{\mathrm{a}}$ & $17.24^{d}$ & $19.12^{d}$ & $6.17^{\mathrm{c}}$ & $7.08^{f}$ \\
\hline
\end{tabular}

Means not sharing the same letter (s) within each column for each are significantly different at 0.05 level of probability.

\section{Effect of foliar application on some leaf micronutrients (B, Fe and Zn $\mathrm{mg} / \mathrm{kg}$ ) contents:}

\subsection{Boron $(\mathrm{mg} / \mathrm{kg})$}

The results given in Table (5) represent the effect of the tested foliar treatments on leaf boron of 'Florida prince' peach during the both studied seasons. The results indicated that zinc sulphate, boric acid and 0.05 Fe-EDTA foliar treatments, significantly increased leaf boron as compared with the control during both seasons of study. While, no significantly differences were recorded among the two foliar applications of $0.1 \%$ and $0.2 \%$ Fe-EDTA foliar treatments and control treatment during both experimental seasons.

A gradual increase in leaf boron with trees treated with $0.2 \% \mathrm{H}_{3} \mathrm{BO}_{3}$ foliar treatment $(95.19 \mathrm{mg} / \mathrm{kg})$, and $0.2 \% \mathrm{ZnSO}_{4}$ foliar treatment $(87.99 \mathrm{mg} / \mathrm{kg})$, followed by $0.2 \% \mathrm{H}_{3} \mathrm{BO}_{3}$ foliar treatment $(86.76 \mathrm{mg} / \mathrm{kg})$, and $0.1 \% \mathrm{ZnSO}_{4}$ foliar treatment $(76.76 \mathrm{mg} / \mathrm{kg})$ as compared with the control $(73.75 \mathrm{mg} / \mathrm{kg})$ in the first season. While, in second season a gradual increase in leaf boron with trees treated with $0.2 \% \mathrm{H}_{3} \mathrm{BO}_{3}$ foliar treatment $(96.08 \mathrm{mg} / \mathrm{kg}), 0.2 \% \mathrm{ZnSO}_{4}$ foliar treatment $(88.85 \mathrm{mg} / \mathrm{kg})$, also $0.1 \% \mathrm{H}_{3} \mathrm{BO}_{3}$ foliar treatment $(87.56 \mathrm{mg} / \mathrm{kg})$, and $0.05 \% \mathrm{H}_{3} \mathrm{BO}_{3}$ foliar treatment $(82.79 \mathrm{mg} / \mathrm{kg})$ as compared with the control (74.56 mg/kg).

The percentage increase of boron in leaves comparing to check plot may be due to the direct effects as reported by Kassem and Marzouk (2004) on mango who found that spraying $\mathrm{Zn}$ increased leaf $\mathrm{K}, \mathrm{Ca}, \mathrm{Mg}$ and $\mathrm{Zn}$ contents, while B sprays increased leaf $\mathrm{K}, \mathrm{Ca}, \mathrm{Mg}$ and $\mathrm{B}$ leaf contents. Also, Abd ElMegeed and Wally (2007) on 'Le-conte' pear trees sprayed with $\mathrm{H}_{3} \mathrm{BO}_{3}$ found that treatment increased leaf boron content as compared with the control treatments. The same conclusion was reported by Aly et al. (2014) on 'Anna' apple trees that B treatment increased leaf boron content $(\mathrm{mg} / \mathrm{kg})$ as compared with control treatment. Also, Abd El-Rahman (2019) on 'Canino' apricot trees 
found that a gradual increase in leaf boron $(\mathrm{mg} / \mathrm{kg}$ ) was observed with trees treated with boric acid at $1.5 \mathrm{~g} / \mathrm{l}$ application treatment as compared with the control during both experimental seasons.

\subsection{Iron (mg/kg):}

Results concerning the effect of foliar application with zinc sulphate, FeEDTA and boric acid on the leaf iron of 'Florida prince' peach during the both 2015 and 2016 seasons are listed in Table (5). In general, the obtained results indicated that Zinc sulphate, Fe-EDTA and Boric acid foliar treatments application, significantly ( $p \leq 0.05)$ increased leaf iron content as compared with the control during both seasons of study. But, no significantly differences were recorded among the $0.2 \% \mathrm{H}_{3} \mathrm{BO}_{3}$ foliar in the second seasons as compared with the control during both seasons study.

A gradual increase in iron leaf was observed with trees treated $0.2 \%$ Fe-EDTA foliar treatment (127.97 and $131.71 \mathrm{mg} / \mathrm{kg}$, each in turn) and $0.2 \%$ $\mathrm{ZnSO}_{4}$ foliar treatment (127.27 and $128.13 \mathrm{mg} / \mathrm{kg}$, serially), followed by $0.1 \%$ Fe-EDTA foliar treatment (126.27 and $128.10 \mathrm{mg} / \mathrm{kg}$, each in turn) as compared with the control (120.24 and $122.21 \mathrm{mg} / \mathrm{kg}$, each in turn) during both 2015 and 2016 seasons. The percentage increase of iron in leaf comparing to check plot may be due to the direct effects of 'Anna' apple trees were sprayed during 2005 and 2006 seasons with $\mathrm{Zn}, \mathrm{Mn}, \mathrm{Mn}$ and Fe sulfate at $1.0 \%$ as well as Boric acid at $400 \mathrm{mg} / \mathrm{L}$, Ascorbic at $1000 \mathrm{mg} / \mathrm{L}$ and Vitamin B complex at $100 \mathrm{mg} / \mathrm{L}$. Spraying with $\mathrm{FeSO}_{4}$, Boric and Vitamin B complex increased leaf $\mathrm{Fe}, \mathrm{Zn}$ and Mn content (Salwa and Khafagy, 2008).

\subsection{Zinc (mg/kg):}

In concerning with influence of zinc sulphate, Fe-EDTA and boric acid foliar applications treatments on the leaf zinc of 'Florida prince' peach during the both 2015 and 2016 seasons, results in Table (5) showed that zinc sulphate, Fe-EDTA and boric acid on the leaf zinc treatments, significantly ( $p \leq 0.05)$ increased leaf zinc as compared with the control during both seasons of study. But, no significantly differences were recorded among the $0.2 \%$ Fe-EDTA foliar treatment and control treatment during both experimental seasons.

The increase in leaf zinc was observed with trees treated with $0.2 \%$ $\mathrm{ZnSO}_{4}$ foliar treatment (32.64 and $34.01 \mathrm{mg} / \mathrm{kg}$, each in turn) and $0.1 \% \mathrm{ZnSO}_{4}$ foliar treatment (29.03 and $30.62 \mathrm{ppm}$, serially), followed by $0.05 \% \mathrm{ZnSO}_{4}$ foliar treatment (25.07 and $26.13 \mathrm{mg} / \mathrm{kg}$, each in turn) as compared with the control (20.27 and $21.69 \mathrm{mg} / \mathrm{kg}$, each in turn) during both seasons of study.

The percentage increase of zinc in leaf comparing to check plot may be due to the direct effects as reported by Kassem and Marzouk. (2004) on mango who found that Spraying $\mathrm{Zn}$ increased leaf $\mathrm{K}, \mathrm{Ca}, \mathrm{Mg}$ and $\mathrm{Zn}$ contents, while B sprays increased leaf K, Ca, Mg and B leaf contents. Also, Hasani et al. (2012) studied that effects of foliar sprays of zinc and manganese sulfates on leaf nutrients concentration of pomegranate, foliar sprays of $\mathrm{Zn}$ significantly increased $\mathrm{Zn}$, but decreased $\mathrm{Mn}$ and $\mathrm{P}$ concentrations in the leaves. 
Table (5). The influence of the foliar application of zinc, boron and iron on leaf $\mathrm{B}, \mathrm{Fe}$ and $\mathrm{Zn}$ content of 'Florida prince' peach trees during 2015 and 2016 seasons

\begin{tabular}{|c|c|c|c|c|c|c|}
\hline \multirow[t]{2}{*}{ Treatments } & \multicolumn{2}{|c|}{$\begin{array}{c}B \\
(\mathrm{mg} / \mathrm{kg})\end{array}$} & \multicolumn{2}{|c|}{$\begin{array}{c}\text { Fe } \\
(\mathrm{mg} / \mathrm{kg})\end{array}$} & \multicolumn{2}{|c|}{$\begin{array}{c}\mathrm{Zn} \\
(\mathrm{mg} / \mathrm{kg})\end{array}$} \\
\hline & 2015 & 2016 & 2015 & 2016 & 2015 & 2016 \\
\hline 1- Control & $73.75^{\mathrm{g}}$ & $74.56^{h}$ & $120.24^{f}$ & $122.21^{f}$ & $20.27^{f}$ & $21.69^{9}$ \\
\hline $2-0.05 \% \mathrm{ZnSO}_{4}$ & $75.85^{f}$ & $76.70^{f}$ & $121.41^{\mathrm{e}}$ & $122.45^{f}$ & $25.07^{c}$ & $26.13^{\mathrm{c}}$ \\
\hline 3- $0.1 \% \mathrm{ZnSO}_{4}$ & $76.76^{\mathrm{e}}$ & $78.06^{\mathrm{e}}$ & $124.11^{\mathrm{c}}$ & $126.07^{\mathrm{c}}$ & $29.03^{\mathrm{b}}$ & $30.62^{\mathrm{b}}$ \\
\hline $4-0.2 \% \mathrm{ZnSO}_{4}$ & $87.99^{b}$ & $88.85^{\mathrm{b}}$ & $127.27^{\mathrm{b}}$ & $128.13^{b}$ & $32.64^{a}$ & $34.01^{a}$ \\
\hline 5- $0.05 \% \mathrm{H}_{3} \mathrm{BO}_{3}$ & $81.79^{d}$ & $82.79^{d}$ & $124.39^{c}$ & $124.87^{d}$ & $21.14^{e}$ & $22.20^{f}$ \\
\hline $6-0.1 \% \mathrm{H}_{3} \mathrm{BO}_{3}$ & $86.76^{\mathrm{c}}$ & $87.56^{\mathrm{C}}$ & $122.58^{d}$ & $123.45^{\mathrm{e}}$ & $22.75^{d}$ & $23.75^{\mathrm{e}}$ \\
\hline 7- $0.2 \% \mathrm{H}_{3} \mathrm{BO}_{3}$ & $95.19^{a}$ & $96.08^{a}$ & $120.79^{\mathrm{ef}}$ & $121.32^{\mathrm{g}}$ & $22.69^{d}$ & $24.73^{d}$ \\
\hline 8- $0.05 \%$ Fe-EDTA & $74.37^{\mathrm{g}}$ & $75.46^{9}$ & $123.55^{\mathrm{cd}}$ & $124.67^{d}$ & $20.52^{f}$ & $20.20^{h}$ \\
\hline $9-0.1 \%$ Fe-EDTA & $72.15^{\mathrm{h}}$ & $73.09^{i}$ & $126.27^{b}$ & $128.10^{b}$ & $21.34^{\mathrm{e}}$ & $22.10^{\mathrm{fg}}$ \\
\hline 10- $0.2 \%$ Fe-EDTA & $69.19^{i}$ & $70.00^{\mathrm{j}}$ & $127.97^{a}$ & $131.71^{\mathrm{a}}$ & $19.65^{\mathrm{g}}$ & $18.61^{i}$ \\
\hline
\end{tabular}

\section{REFERENCES}

Abd El- Megeed, Nagwa A. and A.S.M. Wally (2007). Effect of Calcium and Boron treatments on yield, fruit quality, leaf and fruit mineral contents of pear trees grown in calcareous soil. J. Adv. Agric. Res., (Fac. Agric. Saba Basha), 13 (3):459-477.

Abd El-Rahman, M. A. I (2019). Foliar application of kelpak, brassinolide and boron in relation to fruit set, drop, yield and fruit quality of Canino apricot trees. M.Sc. Thesis, Fac. Agric., Saba Bacha, Alex. Univ.

Aly, M. A, Thanaa, M. Ezz, Nagwa A. Abd El-Megeed and Fatma A. Naseb (2012). Improving 'Le-Conte' pear trees productivity by foliar application with plant bioregulators and boric application with plant bioregulators and boric acid. J. Adv. Agric. Res.,17 (3):622-642.

Aly, M. A., M. M. Harhash, Nagwa A. Abd El-Megeed and R.A. Medan (2014). Response of 'Anna' apple trees to foliar application of some mineral nutrients. J. Adv. Agric. Res.,9 (2): 288-306.

AOAC (1985). Official methods of analysis pp 490-510. Association of Official Analytical Chemists. Washington, D.C.

Asad, A.A. Samia, Nagwa A. Abd El-Megeed and S. Eman Atalla (2013). Effect of foliar application of micronutrients on 'Le-Cont' pear trees under calcareous soil conditions. J. Amer. Sci., 9(75): 123-128.

Bahadur, L., C.S. Malhi, and Z. Singh (1998). Effect of foliar and soil application of zinc sulphate on zinc uptake, tree size, yield and fruit quality of mango. J. Plant Nutr., 21 (3): 589-600.

Benson, N. R., C. G. Woodbridge and R. D. Bartram (1983). Nutrient disorders in tree fruits. Copyright by PNW, 121, Oregon State Univ.

Carter, M.R. (1993). Soil sampling and methods of analysis. Canadian society of soil Science, Lewis Publishers, London, Tokyo.

Chen, B.M. and W.M. Mellenthin (1981). Effect of harvest date on ripening capacity and post- harvest life of Anjou pears. J. Amer. Soc. Hort. Sci., 106: 38-42. 
FAOSTAT (2017). Food and Agriculture Organization of the United Nations statistics division. Internet site available at: (http:// faostat3. FAO Org.)

Hasani, M.; Z. Zamani ; G.S. Avaghebi and R. Fatahi (2012). Effects of Zinc and Manganese as foliar spray on Pomegranate yield, fruit quality and leaf minerals. J. Soil Sci. and Plant Nutr., 25: 222-229.

Hatcher, J. T. and V. Wilcox (1950). Colorimetric determination of Boron using carmine.

James, H., R. Larue and R. Scott Johnson (1989). Peaches, plums and nectarines growing and handling for fresh market. Univ. Calif. Div. Agric. Nat. Res. Publication (3331).

Kassem, H.A. and H.A. Marzouk (2004). Fruit retention, yield and postharvest fruit quality of Mango in relation to: II. Time and Number of Potassium Nitrate, Zinc and Boron Foliar Sprays J. Adv. Agric. Res., (Fac. Ag. Saba Basha) Vol. 9 (2): 299- 311.

Khalifa, R.Kh.M., M. Omaima, Hafez and Hafez and H.Abd- El-Khair (2009). Influence of foliar spraying with Boron and Calcium on productivity, fruit quality, nutritional status and controlling of blossom end rot disease of Anna apple trees. World J. of Agric. Sci., 5 (2): 237-249.

Kilany, E. A. and A.O. Kilany (1991). Effect of potassium and boron nutrients on growth yield and fruit quality of 'Anna' apple trees. Bull Fac. Of Agric. Univ. of Cairo, 42: 415-428.

Larue, J.H. and R.S. Johnson (1989). Peaches, Plums and Nectarines growing and handling for fresh market Copyright the Regent of the Univ.of Calif., Division of Agric. And Ntural Resources pub., 3331,74-81.

Mahnaz, A., E. Saeid and T. Enayat (2010). Interaction of Paclobutrazol, Boron and Zinc on Vegetative Growth, Yield and Fruit Quality of Strawberry (Fragaria $\times$ Ananassa Duch. Cv. Selva) J. Biol. Environ. Sci., 4: 67-75.

Mahrous, H.A.H. and E.M.M. El-Fakhrani (2000). Effect of some dormancy breaking agents on productivity, fruit quality and powdery mildew severity of apricot. Acta Hort. (ISHS) 701:659-664.

Malik,C.P.and M.B. Singh(1980). Plant enzymology and histoenzymology. A text manual, kalyani publishers, New Delhi.

Magness, J. R. and G. F. Taylor (1982). An improved type of pressure tester for the determination of fruit maturity. U. S. Dept. Agri. Circ., 50:8 pp.

Mansour, N.M.; A. Hamouda and G.R. Stino (1982). The adaptability of some imported peach cultivars in Egypt. Fac. Agric., Aim-Shams univ., Ciro, Res. Bull. 1836.

Mostafa, M. F., M. S. El-boray and M.A. Iraqi (1999). Effect of potassium and boron application on yield, fruit quality and leaf mineral content of Anna apple trees. J. Agric. Sci. Mansoura Univ., 24 (9): 4965-4977.

Orphanos, P.I. (2000). Spray and soil application of zinc to apples. The Journal of Horticultural Science \& Biotechnology Vol. 57 No: 3 (Abstract).

Pahlsson, B. (1989). Toxicity of heavy metals (ZN, CU, Cd, Pb) to vascular plants. Physiological studies of rice. I.R.R.I. Manila, Philippnes. Water Air Soil Pollut. 47 (3-4): 287-319.

Rabino, L.,L. Alberto and M.K. Monrad (1977). Photocontrol of anthocyanin synthesis. J. Plant Phy., 59: 569-573. 
Salwa, A. and M. Khafagy (2008). Effect of foliar application with some micronutrients, Ascorbic acid and Vitamin B complex on leaf nutrients content, fruiting and fruit quality of 'Anna' apple trees. By walaa on June 15, 2007 Catrina Journal : Archive_: Volume 2 (2007).

Shaltout, A.D. (1995). Introduction and production of some low-medium Chill peach and apple cultivars in Sub-tropical climate of Egypt. Assiut. J. Agric. Sci., 26(1): 195-206.

Snedecor, G.W. and W.G. Cochran (1990). Statistical methods. Oxford and J.B.H. Bub. Com. $6^{\text {th }}$ Edition. pp: 507.

Stino, G. R., N. M. Mansour and A.H. Hamouda (1982). Characters of four American peach cultivars grown in Egypt. Res. Bulletin No. 2082 December, Fac. Agric. Aim-Shams Univ., Cairo, Egypt.

Wally, A. S., Nagwa, A Abd El-Megeed and H. M. Sherif (2012). Effect of zinc and Urea foliar spray on growth, yield and fruit quality of 'Canino' apricot trees grown in sandy soil. Annals Agric. Sci., Moshtohr. 50(1): 31-42.

Westwood, M.N. (1993). Temperate-Zone Pomology (Physiology and Culture), $3^{\text {rd }}$ ed. Timber Press Inc., Portland, Oregon, USA, 488p.

Wojcik, P. (2002). Yield and fruit (Jon gold) quality as influenced by spring sprays with commercial Rosa top material containing Calcium and Boron. $\mathrm{J}$ of Plant nutrition, 25(50). 999-1010.

Wolf, B. (1982). A comprehensive system of leaf analysis and its use for diagnosing crop nutrition status. Commu. Soil Sci, Plant Anal. 13: 10351059. 


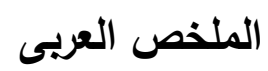

\section{تأثير الرش ببعض العناصر الصغرى على أشجار الخوخ صنف ' فلوريدا برنس،}

\section{محمود أحمد محمد على', ثناء مصطفى عز' , نجوى أبوالمجد عبد المجيد',

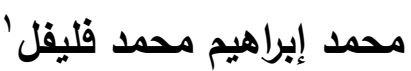

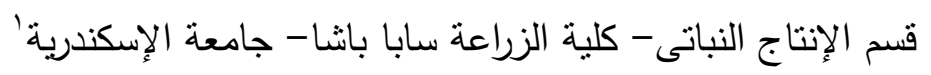

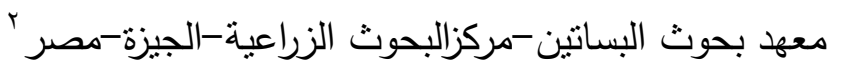

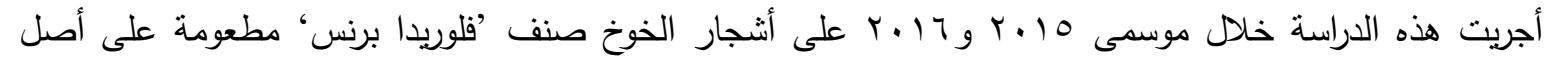
الخوخ نيماجارد عمرها ه سنوات منزرعة فى تربة رملية نروى بنظام الرى بالتتقيط بمزرعة خاصة فى منطقة النوبارية

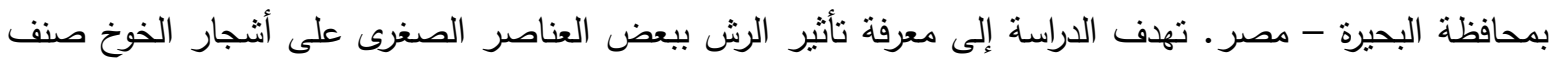

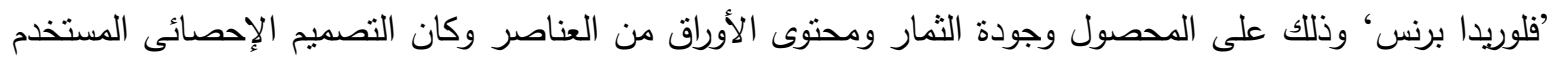

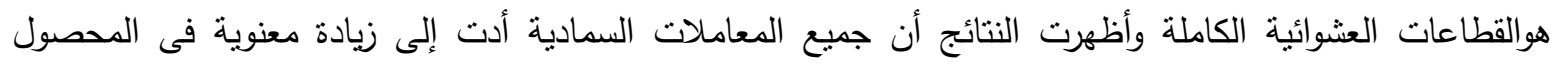

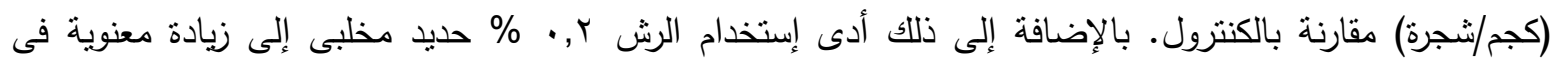

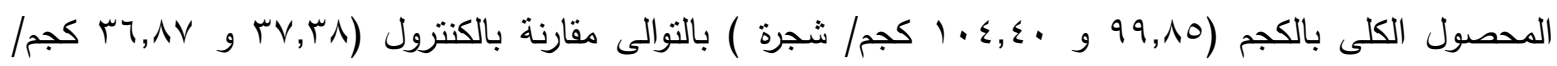

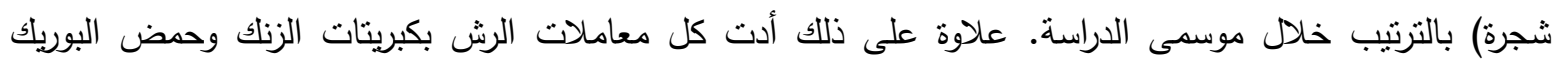

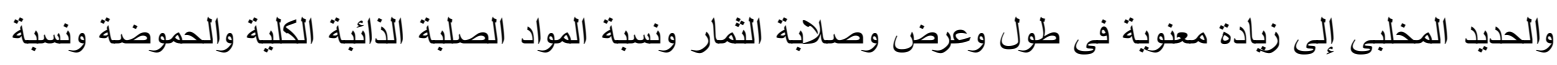

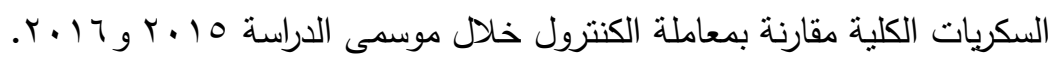

